\title{
Radio-transparent ceramic materials of spodumene-cordierite composition
}

\author{
A.V.Zaichuk ${ }^{1}$, A.A.Amelina ${ }^{1}$, Y.V.Karasik ${ }^{1}$, \\ Y.S.Khomenko ${ }^{1}$, V.A.Lementareva ${ }^{1}$, D.Yu.Saltykov ${ }^{2}$ \\ ${ }^{1}$ State Higher Educational Institution "Ukrainian State University of \\ Chemical Technology", 8 Haharina Ave., 49005 Dnipro, Ukraine \\ ${ }^{2}$ O.Honchar Dnipro National University, 72 Haharina Ave., \\ 49010 Dnipro, Ukraine
}

Received August 10, 2018

The paper deals with the processes of obtaining radio-transparent ceramic materials with a complex of high physical and chemical indices. Directional regulation of the ceramics' microstructure and phase composition was carried out by introducing $\mathrm{Li}_{2} \mathrm{O}-$ $\mathrm{Al}_{2} \mathrm{O}_{3}-\mathrm{B}_{2} \mathrm{O}_{3}-\mathrm{SiO}_{2}$ (LABS) glass into main matrix that consisted of cordierite phase. Optimal composition and temperature conditions for firing of the developed spodumene-cordierite ceramics were established. It is shown that the introduction of LABS glass into experimental compositions contributes to significant intensification of the process of formation of $\alpha$-cordierite crystalline phase, as well as sintering of ceramic materials obtained. Besides, the product of crystallization of parent glass is $\beta$-spodumene which promotes the reduction of CLTE of the obtained ceramic material, on average, to (12.417.8) $\cdot 10^{-7} \mathrm{deg}^{-1}$. The highest indices of mechanical compressive strength (165.8$202.6 \mathrm{MPa}$ ) and thermal stability (not lower than $1050^{\circ} \mathrm{C}$ ) are achieved at the most rational content of LABS glass is 10-20 wt. \%. Under this composition the water absorption is within $0.28-0.34 \%$, apparent density $2.16-2.18 \mathrm{~g} / \mathrm{cm}^{3}$, CLTE (16.6-17.8) $10^{-7} \mathrm{deg}^{-1}$. Studies of electrophysical properties of the developed material at the frequency of $10^{10} \mathrm{~Hz}$ showed that the level of the dielectric constant $(\varepsilon=3.8)$ and dielectric losses $(\operatorname{tg} \delta=$ 0.0014) spodumene-cordierite ceramics synthesized at reduced temperature of 1300$1350^{\circ} \mathrm{C}$ are fully complied with the requirements to the modern radio-transparent materials.

Keywords: radio-transparent ceramic materials, spodumene, cordierite, glass phase, crystallization, physical and technical properties.

\footnotetext{
Исследованы процессы получения радиопрозрачных керамических материалов с комплексом высоких физико-технических показателей. При этом осуществляли направленное регулирование микроструктуры и фазового состава керамики путем введением литий-алюмоборосиликатного стекла в состав основной матрицы, роль которой выполняла кордиеритовая фаза. Установлены оптимальный состав и температурный режим обжига разработанной сподуменкордиеритовой керамики. Показано, что введение в состав опытных композиций литий-алюмоборосиликатного стекла способствует существенной интенсификации процесса формирования кристаллической фазы $\alpha$-кордиерита, а также спеканию полученных керамических материалов. Кроме того, продуктом кристаллизации исходного стекла является $\beta$-сподумен, который способствует снижению ТКЛР полученного керамического материала в целом до $(12,4-17,8) \cdot 10^{-7}$ град $^{-1}$. Для достижения наиболее высоких показателей механической прочности на сжатие $\left(165,8-202,6 \mathrm{MПа)} \mathrm{и} \mathrm{термостойкости} \mathrm{(не} \mathrm{ниже} 1050^{\circ} \mathrm{C}\right)$ наиболее рациональное содержание литий-алюмоборосиликатного стекла составляет 10-20 масс.\%. При этом водо-
} 
поглощение находится в пределах 0,28-0,34 \%, кажущаяся плотность 2,16-2,18 г/ $\mathrm{cm}^{3}$, ТКЛР $(16,6-17,8) \cdot 10^{-7}$ град $^{-1}$. Исследованиями электрофизических свойств разработанного материала на частоте $10^{10}$ Гц установлено, что по уровню диэлектрической проницаемости $(\varepsilon=3,8)$ и диэлектрических потерь $(\operatorname{tg} \delta=0.0014)$ сподуменкордиеритовая керамика, синтезированная при пониженной температуре $1300-1350^{\circ} \mathrm{C}$, в полной мере соответствует требованиям к современным радиопрозрачным материалам.

Радіопрозорі керамічні матеріали сподуменкордісритового складу. О.В.Зайчук, О.А.Алеліна, О.В.Карасик, О.С.Хоменко, В.О.Лелентарьова, Д.Ю.Салтиков.

Досліджено процеси одержання радіопрозорих керамічних матеріалів з комплексом високих фізико-технічних показників. При цьому здійснено спрямоване регулювання мікроструктури та фазового складу кераміки шляхом введення літій-алюмоборосилікатного скла до складу основної матриці, роль якої виконувала кордієритова фаза. Встановлено оптимальний склад та температурний режим випалу розробленої сподуменкордієритової кераміки. Показано, що введення до складу дослідних композицій літій-алюмоборосилікатного скла сприяє суттєвій інтенсифікації процесу формування кристалічної фази $\alpha$-кордієриту, а також спіканню одержаних керамічних матеріалів. Крім того, продуктом кристалізації вихідного скла $є \beta$-сподумен, який сприяє зниженню ТКЛР отриманого керамічного матеріалу в цілому до $(12,4-17,8) \cdot 10^{-7}$ град $^{-1}$. Для досягнення найбільш високих показників механічної міцності на стискання $(165,8-$ $202,6 \mathrm{MПа)} \mathrm{та} \mathrm{термостійкості} \mathrm{(не} \mathrm{нижче} 1050^{\circ} \mathrm{C}$ ) найбільш раціональний вміст літійалюмоборосилікатного скла складає 10-20 мас.\%. При цьому водопоглинання знахо-

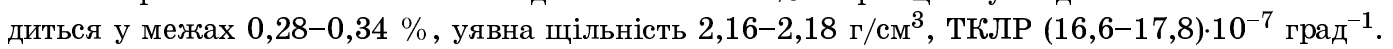
Дослідженнями електрофізичних властивостей розробленого матеріалу на частоті $10^{10}$ Гц встановлено, що за рівнем діелектричної проникності $(\varepsilon=3,8)$ та діелектричних втрат (tg $\delta=0,0014)$ сподуменкордієритова кераміка, яка синтезована при зниженій температурі $1300-1350^{\circ} \mathrm{C}$, у повній мірі відповідає вимогам до сучасних радіопрозорих матеріалів.

\section{Introduction}

Developments in the domain of the aviation and rocket technology, as well as electronics, constantly require the creation of new effective materials with the higher performance in terms of their physical-chemical, mechanical, thermal and radio-technical characteristics. At the present time, quartz ceramics and a number of high-temperature glass-ceramic materials obtained predominantly on the basis of aluminosilicate systems [1-4] are widely used as radio-transparent materials. They are characterized by low dielectric losses $(\varepsilon<10, \operatorname{tg} \delta<0.001)$.

At the same time, despite all efforts made for quartz ceramics strengthening [1, $5,6]$, such ceramics is demonstrating low values of mechanical strength.

Production of glass-ceramic materials on the basis of aluminosilicate systems according to the traditional technology of hightemperature melting of parent glass (1600$1700^{\circ} \mathrm{C}$ and above) with the subsequent long-term crystallization $(15-16 \mathrm{~h}$ and more) is rather complex and energy-intensive process imposing the restraints with regard to complexity of shape of the products themselves.

Wider opportunities for making the products of various shapes and dimensions are given by the use of ceramic (powder) technology with the further directional crystallization of glass. This technology allows using as the parent glass the wide range of crystallizing glass compositions that are not suitable for the classical method. In this case, concentration of the catalyst can be decreased significantly or reduced to zero, since crystallization occurs in the process of firing, where high specific surface area of particles acts as a catalyst [7]. Ceramic technology also provides the increased stability and reproducibility of physical and chemical properties of materials; the temperature of firing mainly does not exceed $1300^{\circ} \mathrm{C}$. The main disadvantages of glass-crystalline materials synthesis while using the powder method include high temperatures of parent glass melting (up to $1500^{\circ} \mathrm{C}$ and above). Besides, there are considerable difficulties in preparation of aqueous slurries with the necessary rheological properties.

High thermal stability is one of the most important performance indicators of radiotransparent materials for making specialpurpose constructions. To this effect, glassceramics on the basis of compositions of system $\mathrm{Li}_{2} \mathrm{O}-\mathrm{Al}_{2} \mathrm{O}_{3}-\mathrm{B}_{2} \mathrm{O}_{3}-\mathrm{SiO}_{2}$ showed rather good results. However, the above types of glass-ceramics feature the heat re- 
sistance, as a rule, not exceeding $1100^{\circ} \mathrm{C}$ [8], as well as insufficient mechanical strength [9].

To overcome these restraints the development with the use of high-temperature alkali-free aluminosilicate glass-ceramics, in particular, cordierite one, as a matrix was chosen. Cordierite phase provides low dielectric losses, high thermal shock resistance and mechanical strength [3, 10, 11].

It should be noted that in terms of manufacturability alkali-free glass-ceramics is refractory, and parent glass melting temperatures reach $1600-2000^{\circ} \mathrm{C}$.

When cordierite is synthesized according to the conventional ceramic technology with the use of traditional technical and natural raw materials it is almost impossible to achieve high indices of physical and technical properties of material because of its unsatisfactory sintering ability at the temperatures below $1500^{\circ} \mathrm{C}$.

Therefore, a great deal of experience has been gained, and certain materials science issues have been solved in the technology of radio-transparent glass-crystalline materials [1-7]. At the same time the existing developments do not contain fundamentally new techniques capable of intensifying the processes of formation of the materials' structure towards achievement of the complex of specified physical and technical indices.

Consequently, the research objective consisted in development of the scientific basis for the energy-efficient technology of radiotransparent ceramics synthesis with the complex of high physical and technical indices. The research was based on establishing physical and chemical patterns and technological principles of the directional regulation of microstructure and phase composition of the experimental ceramic materials.

\section{Experimental}

LABS glass, "cordierite chamotte", Prosyanakaolin of KFN-2 grade, Indian talc of 5SSW, and technical alumina of G0 grade were used for obtaining spodumene-cordierite ceramic materials.

Composition of glass was chosen in the pseudoternary system of $\mathrm{Li}_{2} \mathrm{O}-\mathrm{Al}_{2} \mathrm{O}_{3}-\mathrm{B}_{2} \mathrm{O}_{3}-\mathrm{SiO}_{2}$ (with the constant content of $\mathrm{B}_{2} \mathrm{O}_{3}-10$ wt. $\%$ ); it corresponded to the stoichiometric spodumene and stayed in close proximity to the eutectics with the temperature of $1260^{\circ} \mathrm{C}$ [12]. Melting of the parent glass was carried out in the electric furnace with silicon carbide heating elements in chamotte crucibles at the temperature of $1350^{\circ} \mathrm{C}$ during $1 \mathrm{~h}$. Ob- tained glass was characterized by the coefficient of linear thermal expansion (CLTE) equal to $60.7 \cdot 10^{-7} \mathrm{deg}^{-1}$ [9].

"Cordierite chamotte" acted as a nonplastic material in the compositions under study. For its preparation, kaolin, talc and technical alumina in the ratios necessary for obtaining the stoichiometric cordierite were used. Chamotte was prepared by joint wet grinding $(W=35 \%)$ of the initial raw material components in the ball mill till complete passing through the sieve No0063. Dried material was firing at the maximum temperature of $1200^{\circ} \mathrm{C}$ with the isothermal holding for $1 \mathrm{~h}$. The resulting chamotte was ground in the ball mill till complete passing through the sieve No01.

For comparison of results, along with the compositions containing the LABS glass the basic composition $\mathrm{C}-0$ was considered as well. It consisted of kaolin, talc and technical alumina in the ratios necessary for obtaining stoichiometric cordierite.

Using the initial components, ceramic slurry was prepared by joint wet grinding in the porcelain ball mill till complete passing through the sieve No0063 with the subsequent ageing within $2 \mathrm{~h}$. Using the prepared slurries (of 29-33\% moisture content), samples were cast into plaster molds in the form of cylinders and rods. After removal of castings from the molds they were dried to residual moisture content of $1 \%$. Dried specimens were firing in the furnace with silicon carbide heating elements in the air according to specified temperature-time conditions. Maximum temperature of sintering was equal to $1150-1350^{\circ} \mathrm{C}$ with the isothermal holding for $1 \mathrm{~h}$.

During experimental studies, standard techniques for determination of properties of obtained ceramic materials were used.

Water absorption $(W)$, opened porosity $(P)$ and apparent density $(\rho)$ of samples were determined by the saturation method with the further weighing in the air and in water.

Ultimate compressive strength $(\sigma)$ of specimens in the form of cylinders $(d=h=25 \mathrm{~mm})$ was determined on the hydraulic press.

Coefficient of linear thermal expansion of ceramic materials was determined with the use of the automatic quartz dilatometer in accordance with GOST 10978-2014.

Temperature of softening and crystallization of the parent LABS glass was measured on the derivatograph "Q-1500D" in the temperature interval of $20-1200^{\circ} \mathrm{C}$ at the rate of temperature elevation of $10^{\circ} \mathrm{C} / \mathrm{min}$. 
Crystal-phase composition of the experimental materials was determined by X-ray diffraction (XRD) on the diffractometer DRON-3.0 in $\mathrm{Cu}-\mathrm{K}_{\alpha}$ radiation.

Dielectric constant $(\varepsilon)$ and dielectric loss tangent $(\operatorname{tg} \delta)$ were measured on the unit comprising G4-83 generator, $\mathrm{S} 4-11$ spectral analyzer and bi-conical resonator. The resonator was connected in the transmission mode. Measurements were made at frequency of $10^{10} \mathrm{~Hz}$ and temperature of $20^{\circ} \mathrm{C}$ [13].

\section{Results and discussion}

The paper deals with the processes of obtaining radio-transparent ceramic materials with a complex of high physical and chemical indices. In connection with it, directional regulation of the ceramics' microstructure and phase composition was carried out by introduction of the LABS glass into main matrix consisting of cordierite phase.

Choice of the parent glass composition was conditioned by the fact that in terms of the pseudo-ternary system $\mathrm{Li}_{2} \mathrm{O}-\mathrm{Al}_{2} \mathrm{O}_{3}-$ $\mathrm{B}_{2} \mathrm{O}_{3}-\mathrm{SiO}_{2}$ it corresponded to the stoichiometric spodumene. This phase formed during crystallization of glass ensures low CLTE of ceramic material. Additional introduction of $\mathrm{B}_{2} \mathrm{O}_{3}$ into LAS system allows melting of such glass at relatively low temperature $\left(1350^{\circ} \mathrm{C}\right)$. To our opinion, introducing the LABS glass into experimental compositions should contribute to the significant acceleration of the process of formation of the main crystalline phase $(\alpha-$ cordierite) and densification of the structure of ceramics due to intensification of sintering. Thus the content of the LABS glass within experimental compositions of SC-0...SC-4 was varied within 10-40 wt. $\%$.

To obtain cordierite, such materials as kaolin, talc and technical alumina were used in the stoichiometric ratio.

The resulting process of cordierite formation can be presented by the equation below:

$$
\begin{gathered}
2\left(3 \mathrm{MgO} \cdot 4 \mathrm{SiO}_{2} \cdot \mathrm{H}_{2} \mathrm{O}\right)+ \\
+3.5\left(\mathrm{Al}_{2} \mathrm{O}_{3} \cdot 2 \mathrm{SiO}_{2} \cdot 2 \mathrm{H}_{2} \mathrm{O}\right)+2.5 \mathrm{Al}_{2} \mathrm{O}_{3}= \\
=3\left(2 \mathrm{MgO} \cdot 2 \mathrm{Al}_{2} \mathrm{O}_{3} \cdot 5 \mathrm{SiO}_{2}\right)+9 \mathrm{H}_{2} \mathrm{O} .
\end{gathered}
$$

For comparison of results, the cordierite composition $\mathrm{C}-\mathrm{O}$ without introduction of the glass was considered as well. After preliminary study of such composition the strong tendency to cracking in the process of drying for specimens cast from the aqueous slurry was found. The tendency to deformation and cracking is obviously caused by high content of kaolin and finely dispersed talc in such composition (86.7 wt.\% in total).

Therefore, chamotte was preliminarily prepared from the mixture of initial raw materials of the stoichiometric cordierite composition, which was used as a non-plastic material for reduction of the shrinkage and deformation of specimens. Chamotte was introduced into experimental charges in the amount of up to $40 \mathrm{wt} \%$ instead of the relevant amount of kaolin, talc and technical alumina. Chamotte concentration in the composition was determined by the content of the LABS glass that also acted as a non-plastic material at the stage of specimen drying.

One of the most important stages in the technology of glass crystalline materials is the process of their heat treatment in order to ensure the directional crystallization and subsequent sintering with the formation of specified microstructure of the material. Crystallization and densification are competing processes which can take place both successively and simultaneously. Therefore, it is necessary to set the optimal heat treatment parameters, which provide the formation of specified structure of the material and its phase composition.

Taking into account the data of the differential thermal studies of the parent LABS glass [9], stepwise firing of the experimental materials was performed firstly at the temperatures of softening $\left(600^{\circ} \mathrm{C}\right)$ and crystallization $\left(760^{\circ} \mathrm{C}\right)$ of the parent glass with the isothermal holding during $2 \mathrm{~h}$, and then consequently in the temperature interval of $1150-1350^{\circ} \mathrm{C}$ with $1 \mathrm{~h}$ holding.

As it is found from experiments (Fig. 1), with the increase in the temperature of firing of $\mathrm{C}-0$ composition that contained no parent LABS glass, from 1200 to $1350^{\circ} \mathrm{C}$ the process of sintering is intensified. It resulted in gradual decrease of the indices of water absorption and opened porosity to $15.8 \%$ and $27.8 \%$, accordingly. As a consequence, increase is observed in the density (from 1.44 to $1.77 \mathrm{~g} / \mathrm{cm}^{3}$ ) and ultimate compressive strength (from 21.1 to $90.4 \mathrm{MPa}$ ). Crystal-phase composition of obtained materials undergoes significant changes as well. For example, after firing at the temperature of $1200^{\circ} \mathrm{C}$ a number of new crystalline forms such as $\beta$-cristobalite $\left(d \cdot 10^{-10}=4.00 ; 3.12\right.$; $2.47 ; 1.43 \mathrm{~m})$, clinoenstatite $\mathrm{MgO} \cdot \mathrm{SiO}_{2}\left(d \cdot 10^{-10}\right.$ $=2.11 ; \quad 2.84 ; \quad 2.94 ; 3.12 \mathrm{~m})$, mullite $3 \mathrm{Al}_{2} \mathrm{O}_{3} \cdot 2 \mathrm{SiO}_{2}\left(d \cdot 10^{-10}=5.34 ; 3.40 ; 3.34 ; 2.66\right.$; $2.18 \mathrm{~m}$ ) and small amount of $\alpha$-cordierite $2 \mathrm{MgO} \cdot 2 \mathrm{Al}_{2} \mathrm{O}_{3} \cdot 5 \mathrm{SiO}_{2}\left(d \cdot 10^{-10}=8.21 ; 3.34 ; 2.94\right.$; 

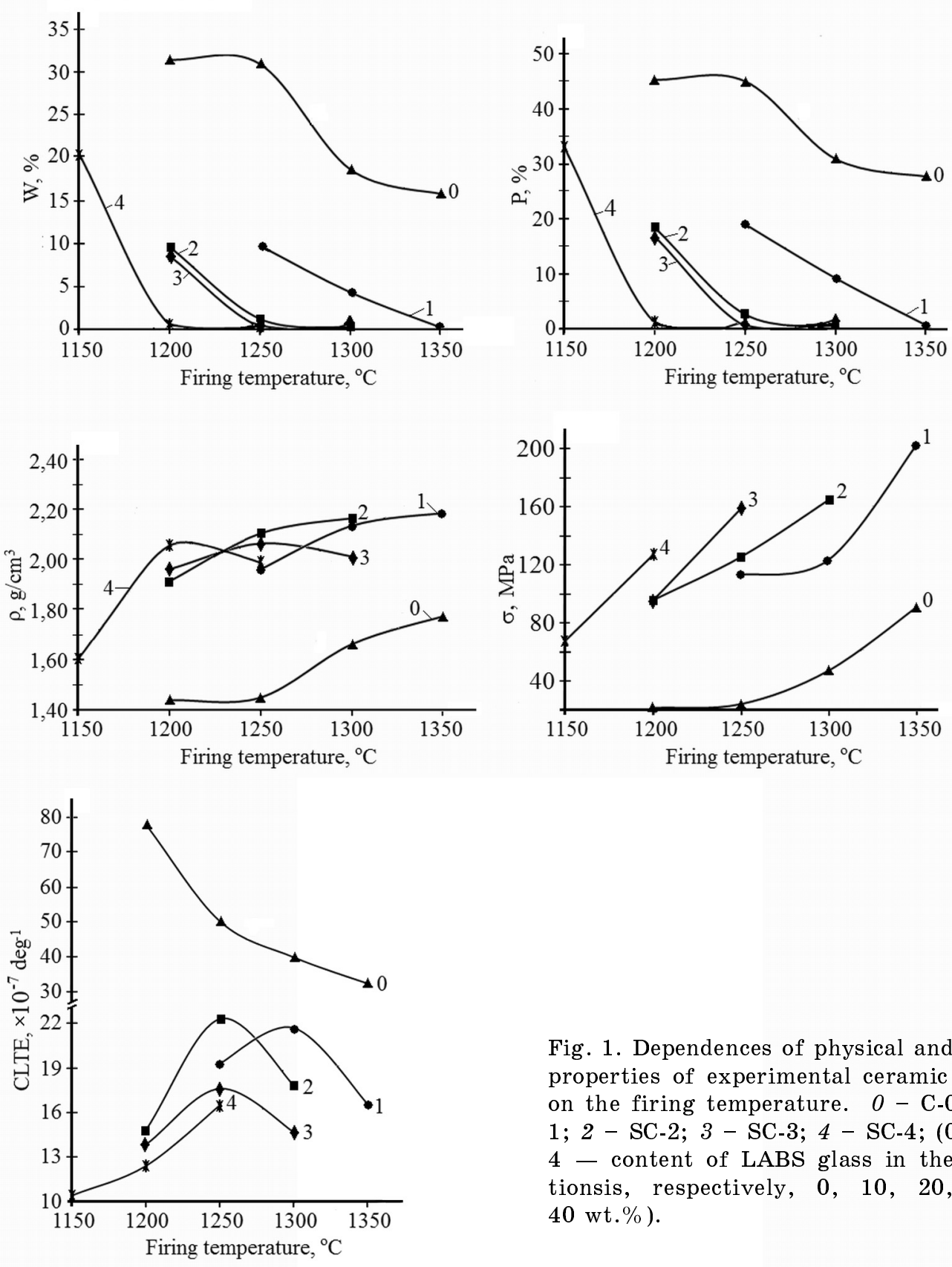

$1.67 \mathrm{~m}$ ) was found in the composition - see data of XRD (Fig. 2). After firing at the temperature of $1350^{\circ} \mathrm{C}$, formation of the cordierite phase in the $\mathrm{C}-0$ composition is actually completed which is evidenced by the data of X-ray diffraction and results of dilatometric measurements $\left(\mathrm{CLTE}_{20-400}=32.5 \cdot 10^{-7} \mathrm{deg}^{-1}\right)$.

Introduction and gradual increase in the content of the LABS glass to $40 \mathrm{wt} \%$ in the compositions under study causes the substantial intensification of the process of cordierite phase formation and sintering of

the material as a whole, which indicates its mineralizing action.

When the experimental glass is introduced in the amount of 30-40 wt\% (SC-3 and SC-4 compositions), the optimal temperature of firing is $1200-1250^{\circ} \mathrm{C}$. Obtained ceramic materials are characterized by minimal indices of water absorption of $0.34-0.49 \%$ and opened porosity of $0.66-1.04 \%$, as well as maximum values of density of $2.04-2.06 \mathrm{~g} / \mathrm{cm}^{3}$ and ultimate compressive strength of 126.4159.2 $\mathrm{MPa}$. In this case CLTE is equal to (12.4-17.6) $10^{-7} \mathrm{deg}^{-1}$. Crystal-phase com- 

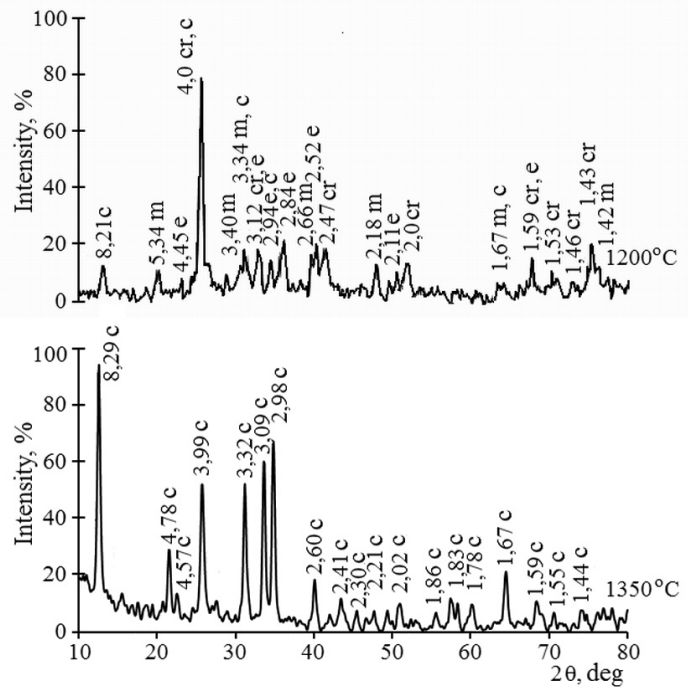

Fig. 2. XRD patterns of C-0 composition. $\mathrm{c}-$ $\alpha$-cordierite; $s-\beta$-spodumene; $\mathrm{m}$ - mullite; $e-$ clinoensatite.

position of obtained materials (Fig. 3) is represented by $\alpha$-cordierite $\left(d \cdot 10^{-10}=8.22\right.$; $4.02 ; 3.33 ; 2.99 \mathrm{~m})$ and $\beta$-spodumene $\left(d \cdot 10^{-}\right.$ $10=3.85 ; 3.42 ; 3.10 ; 2.26 \mathrm{~m})$. The latter is the product of crystallization of the experimental LABS glass. The further increase in the temperature of firing of such compositions to $1250-1300^{\circ} \mathrm{C}$ is not advisable because of severe deformation thereof. It is caused, presumably, by decrease in viscosity of the residual glass phase and further active dissolution of crystalline phases of $\alpha$ cordierite and $\beta$-spodumene in the resulting
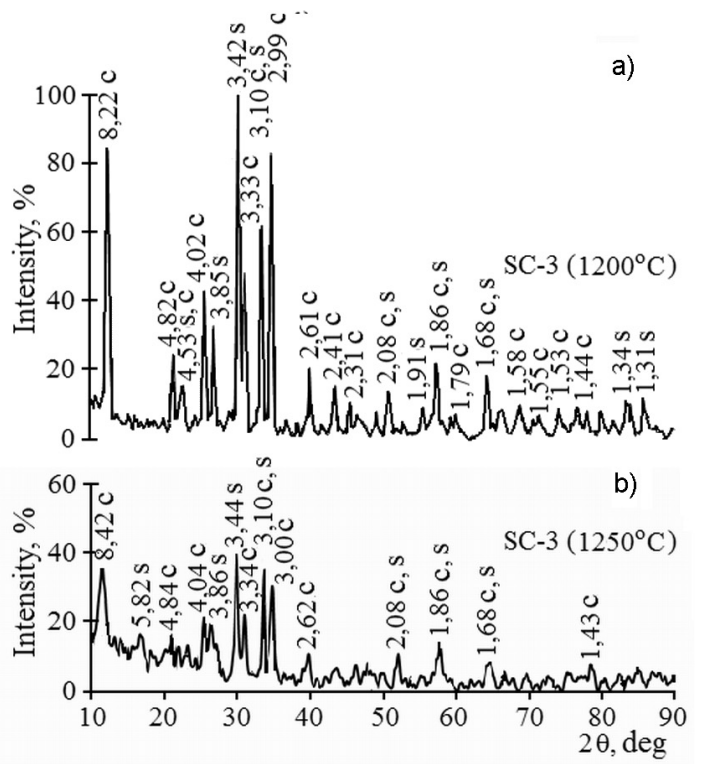

glass melt. This is evidenced by the significant decrease in the intensity of main reflexes which correspond to $\alpha$-cordierite and $\beta$-spodumene on the XRD pattern of sample SC-3 (Fig. 3). This sample was fired at $1250^{\circ} \mathrm{C}$.

When the experimental glass is introduced in the amount of 10-20 wt. \% (SC-1 and SC-2 compositions), the most rational temperature, in terms of achieving a complex of high physical and technical indices is the temperature of firing of 1300$1350^{\circ} \mathrm{C}$. Obtained materials are characterized by low water absorption of $0.28-$ $0.34 \%$, opened porosity of $0.59-0.73 \%$ and high density of $2.16-2.18 \mathrm{~g} / \mathrm{cm}^{3}$ which causes an increase in values of the ultimate compressive strength to 165.8-202.6 $\mathrm{MPa}$. Mineralogical composition of synthesized materials (Fig. 4) is represented mainly by the cordierite phase that is indicated by high intensity of the main diffraction peaks corresponding to it with $d \cdot 10^{-10}=8.29$; $3.99 ; 3.31 ; 3.08 ; 2.98$ m. SC-2 composition containing 20 wt. $\%$ of experimental glass shows rather large amount of $\beta$-spodumene $\left(d \cdot 10^{-10}=3.83 ; 3.42 ; 3.10 ; 1.92 \mathrm{~m}\right)$ as well. For SC-1 composition containing 10 wt. $\%$ of the experimental glass, presence of $\beta$ spodumene is recorded after firing at the temperature of $1250^{\circ} \mathrm{C}$ only (see data of Fig. 4a). The subsequent increase in the temperature of sintering to $1300^{\circ} \mathrm{C}$ causes dissolution of spodumene phase, and increase to $1350^{\circ} \mathrm{C}$ results in the partial dissolution of cordierite phase in the glass melt, viscosity of which is reduced with the increase in temperature.

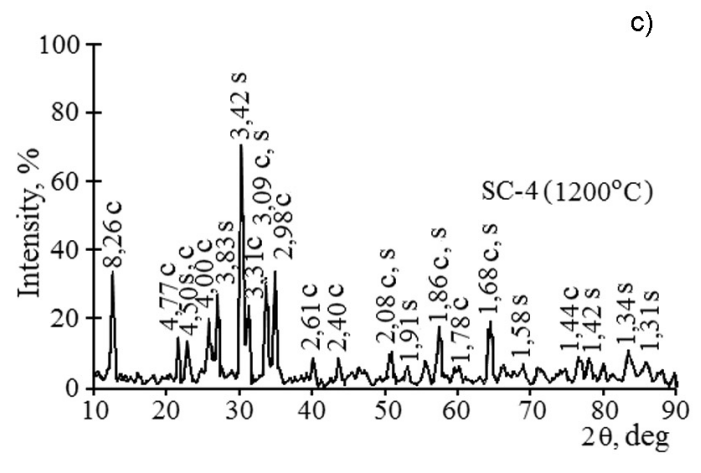

Fig. 3. XRD patterns of SC-3 and SC-4 compositions synthesized at various temperatures; $c$ - cordierite; $s-\beta$-spodumene. 

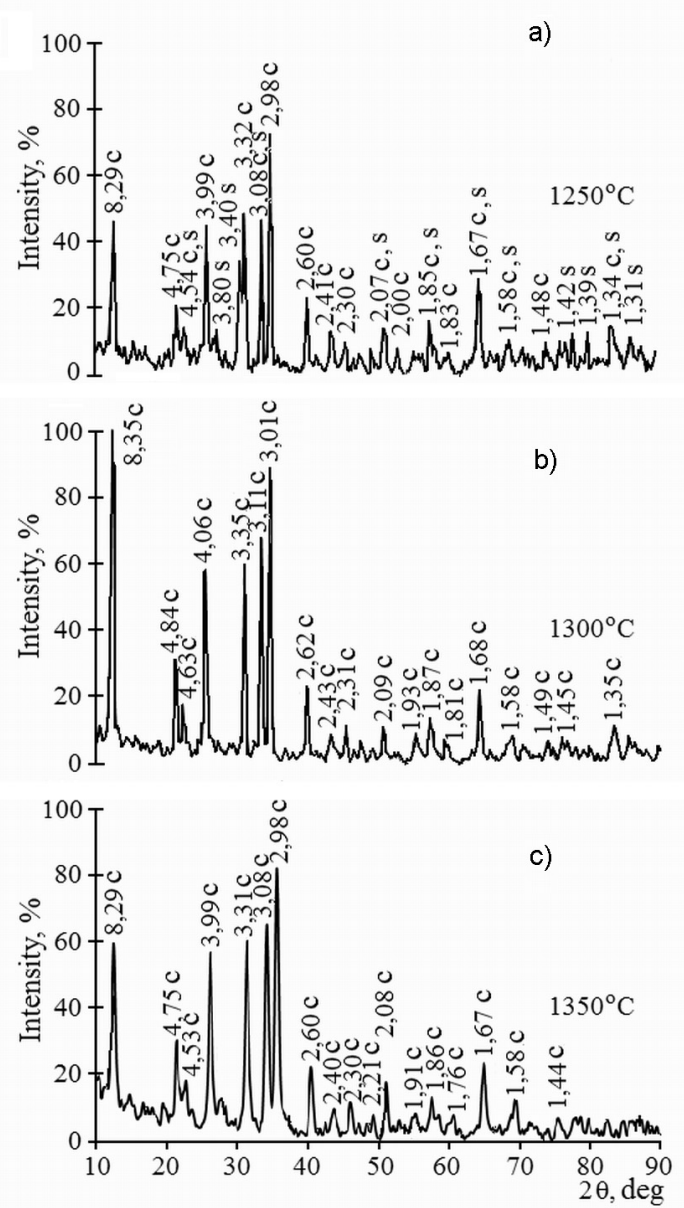

Sharp dependence for the coefficient of linear thermal expansion of the experimental compositions on the firing temperature is observed. For example, with the increase in temperature to $1250-1300^{\circ} \mathrm{C}$ the growth of CLTE values from $(14.8-19.3) \cdot 10^{-7} \mathrm{deg}^{-1}$ to $(21.7-22.3) \cdot 10^{-7} \mathrm{deg}^{-1}$ takes place. The further sintering at the temperatures of $1300-1350^{\circ} \mathrm{C}$ results in decrease of CLTE in the range of $20-400^{\circ} \mathrm{C}$ to $(16.6-17.8) \cdot 10^{-7} \mathrm{deg}^{-1}$, which is obviously caused by the reduction of content of $\alpha$-cordierite crystalline phase because of its partial dissolution in the glass melt (Fig. 4). Increase in the amount of glass phase in the structure of obtained materials stipulates their densification $(\rho=$ $2.16-2.18 \mathrm{~g} / \mathrm{cm}^{3}$ ) and significant growth of values of the ultimate compressive strength to 165.8-202.6 MPa (Fig. 1).

For SC-1 composition featuring the highest strength and thermal-physical indices the dielectric constant $\varepsilon$ and dielectric loss tangent $\operatorname{tg} \delta$ were determined, which at frequency of $10^{10} \mathrm{~Hz}$ and temperature of $20^{\circ} \mathrm{C}$ were equal to 3.8 and 0.0014 , accordingly. Low values of
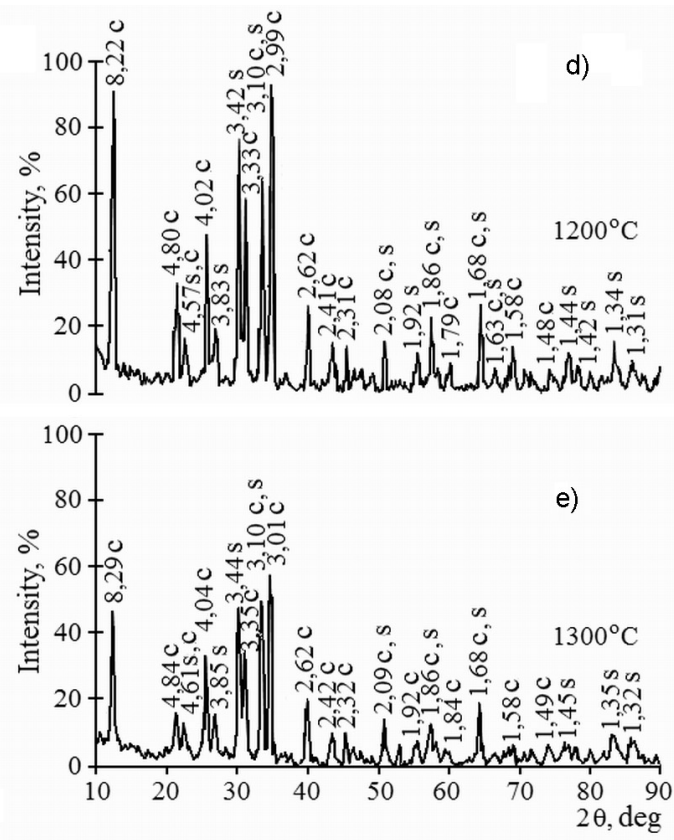

Fig. 4. XRD patterns of SC-1 (a,b,c), SC-2 $(d$, e) compositions synthesized at various temperatures, $c-\alpha$-cordierite; $s-\beta$-spodumene.

$\varepsilon$ and $\operatorname{tg} \delta$ confirm that spodumene-cordierite ceramics developed at low temperatures fully complies with the requirements to the modern radio-transparent materials.

Experimental thin-walled (4 $\mathrm{mm}$ thick) specimens of conical shape were made of SC-1 composition at the temperature of $1350^{\circ} \mathrm{C}$ for the demonstration purposes. The resulting specimens were characterized by precision of the shape, without any manifestations of deformation processes, and showed high thermal stability of not lower than $1050^{\circ} \mathrm{C}$.

\section{Conclusions}

Therefore, in the course of studies the authors established physical and chemical patterns and technological principles of the directional regulation of microstructure and phase composition of radio-transparent ceramic materials. It is found that the LABS glass introduced into experimental cordierite compositions produces the effective mineralizing action. As a result, substantial intensification of the process of the main crystalline phase formation of $\alpha$-cordierite and densification of the structure of the 
obtained ceramic material takes place. Besides, stepwise heat treatment of the experimental compositions according to specified temperature-time conditions provides crystallization of glass with the formation of $\beta$-spodumene phase. This crystalline phase contributes to the reduction of CLTE of the ceramic material mainly to the values of (12.4-17.8) $\cdot 10^{-7} \mathrm{deg}^{-1}$. Consequently, in the range of $1200-1350^{\circ} \mathrm{C}$ the materials of spodumene-cordierite composition with a complex of high physical and technical indices were synthesized, in particular, with low values of water absorption (0.28$0.49 \%)$ and opened porosity $(0.59-1.04 \%)$ which stipulated their high apparent density $\left(2.05-2.18 \mathrm{~g} / \mathrm{cm}^{3}\right)$. In order to achieve the highest indices of mechanical compressive strength (165.8-202.6 MPa) and thermal stability (not lower than $1050^{\circ} \mathrm{C}$ ) the most rational content of the LABS glass is defined within 10-20 wt. \%. The studies of electro-physical properties of the developed material showed that in terms of the level of the dielectric constant $(\varepsilon=3.8)$ and dielectric losses $(\operatorname{tg} \delta=0.0014)$ spodumenecordierite ceramics synthesized at reduced temperature of $1300-1350^{\circ} \mathrm{C}$ fully complied with the requirements to the modern radiotransparent materials.

\section{References}

1. Yu.E.Pivinsky, E.I.Suzdaltsev, Heat-power Engineer, Moscow (2008) [in Russian].

2. N.E.Uvarova, D.V.Graschenkov, N.V.Isaeva et al., J.Aviat. Mater. Tech., 1, 16 (2010).

3. E.N.Kablov, D.V.Graschenkov, N.V.Isaeva et al., Glass and Ceramics, 4, 7 (2012).

4. U.S.Corning, E.D.Zanotto, J.Am.Ceram.Soc. Bull., 89, 19 (2010).

5. A.V.Zaychuk, A.A.Amelina, Voprosy Khimii $i$ Khimich. Tekhn., 6, 63 (2017).

6. E.S.Khomenko, E.V.Karasik, V.I.Goleus, Functional Materials, 24, 593 (2017).

7. P.D.Sarkisov, D.V.Graschenkov, L.A.Orlovaet et al., Techn. Techn. Silicates, 16, 2 (2009).

8. E.I.Suzdal'tsev, T.I.Rozhkova, Refractories and Indust. Ceramics, 44, 260 (2003).

9. A.Zaychuk, C.Dimitrov, A.Amelina, D.Wedmid, Rusenskaya University "Angel Kanchev", Ser. 10.1 Chemistry Technology, 56, 96 (2017).

10. Z.Shamsudin, A.Hodzic, C.Soutis et al., $J$. Mater. Sci., 46, 5822 (2011).

11. O.V.Savvova, S.M.Logvinko, O.V.Babich, A.R.Zdorik, Voprosy Khimii $i$ Khimich. Tekhn.., 3, 96 (2018).

12. K.H.Kim, F.A.Hummelin, Book Introduction to Phase Equilibria in Ceramic Systems, Basel, New York (1984).

13. M.V.Andreev, O.O.Drobakhin, Ye.N.Privalov, D.Yu.Saltykov, Telecommun. and Radio Engin., 73, 1017 (2014). 